\title{
Summary of Bed-Sediment Measurements Along the Platte River, Nebraska, 1931-2009
}

\author{
By P.J. Kinzel' and J.T. Runge ${ }^{2, *}$
}

\section{Introduction}

Rivers are conduits for water and sediment supplied from upstream sources. The sizes of the sediments that a river bed consists of typically decrease in a downstream direction because of natural sorting. However, other factors can affect the caliber of bed sediment including changes in upstream water-resource development, land use, and climate that alter the watershed yield of water or sediment. Bed sediments provide both a geologic and stratigraphic record of past fluvial processes and quantification of current sediment transport relations. The objective of this fact sheet is to describe and compare longitudinal measurements of bed-sediment sizes made along the Platte River, Nebraska from 1931 to 2009.

The Platte River begins at the junction of the North Platte and South Platte Rivers near North Platte, Nebr. and flows east for approximately 500 kilometers before joining the Missouri

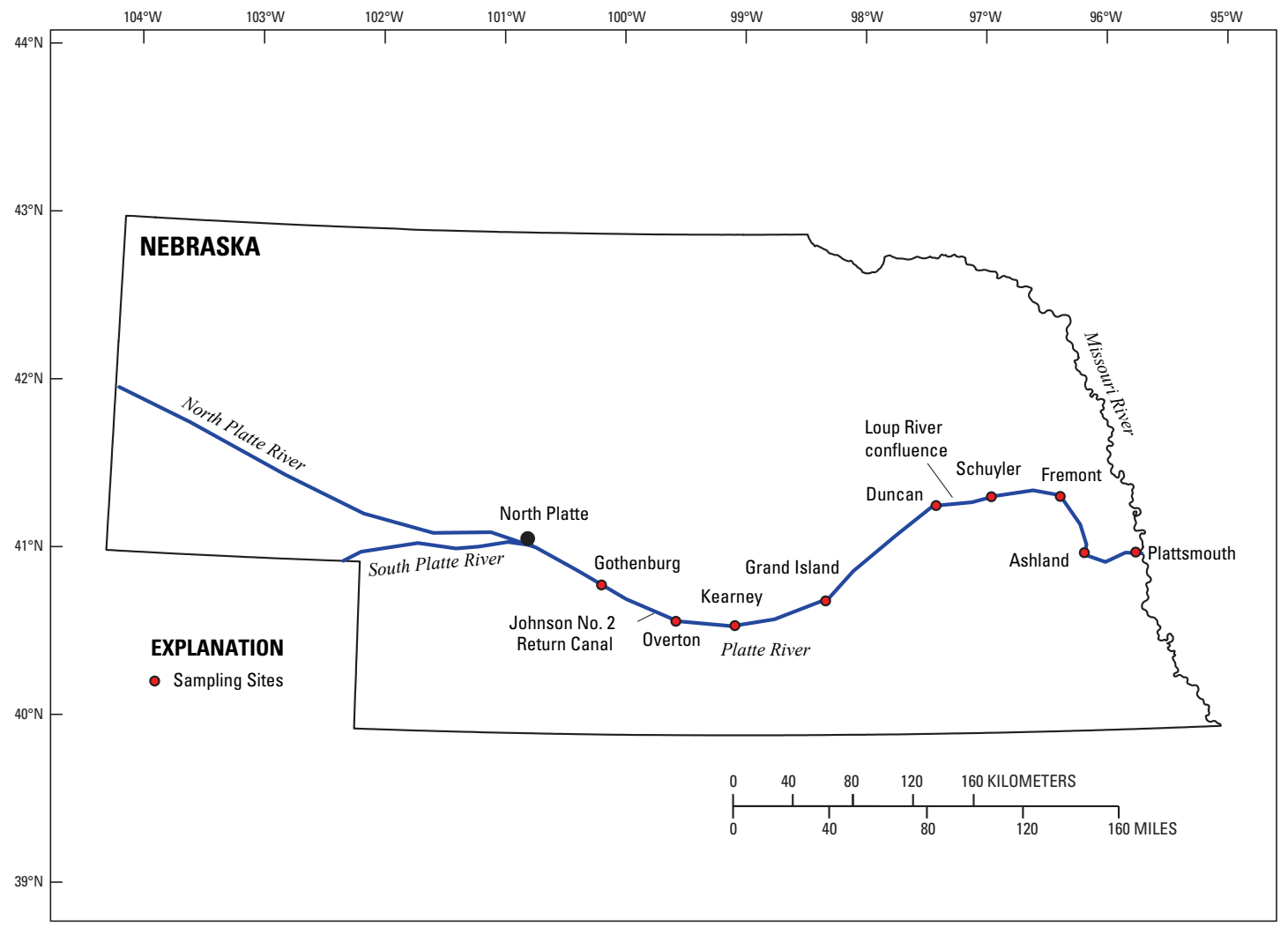

${ }^{1}$ U.S. Geological Survey Geomorphology and Sediment Transport Laboratory, Golden, Colorado.

${ }^{2}$ U.S. Fish and Wildlife Service, Grand Island, Nebraska.

*The findings and conclusions in this fact sheet do not necessarily represent the views of the U.S. Fish and Wildlife Service.
River at Plattsmouth, Nebr. (fig. 1). The confluence of the Loup River with the Platte River serves to divide the middle (or central) Platte River (the Platte River upstream from the confluence with the Loup River) and lower Platte River (the Platte River downstream from the confluence with Loup River). The Platte River provides water for a variety of needs including: irrigation, infiltration to public water-supply wells, power generation, recreation, and wildlife habitat. The Platte River Basin includes habitat for four federally listed species including the whooping crane (Grus americana), interior least tern (Sterna antillarum), piping plover (Charadrius melodus), and pallid sturgeon (Scaphirhynchus albus) (National Research Council, 2004). A habitat recovery program for the federally listed species in the Platte River was initiated in 2007 (Governance Committee, 2006). One strategy identified by the recovery program to manage and enhance habitat is the manipulation of streamflow. Understanding the longitudinal and temporal changes in the size gradation of the bed sediment will help to explain the effects of past flow regimes and anticipated manipulation of streamflows on the channel morphology and habitat.

Figure 1. Selected bedsediment sampling sites located near cities along the Platte River. 


\section{Field and Data Reduction Methods}

A brief description of the field methods used by each investigator to sample the bed sediment is included in the following sections. Also described are the methods used to combine multiple samples collected at a site, combine sedimentsize distributions to form a single composite distribution, and determine a composite median size than can be used for comparisons (fig. 2).

\section{U.S. Army Corps of Engineers, 1931}

In the early 1930s the U.S. Army Corps of Engineers, as part of a general plan for the development of the Missouri River Basin, investigated the sediment characteristics of the Missouri River and its major tributaries (U.S. Army Corps of Engineers, 1931). Eight sites along the Platte River were selected for sampling (fig. 2). At each site sediment samples were collected at multiple of points across the river channel with an "orange peel bucket" commonly used for well digging. The sampler was lowered from a bridge until it reached the river bottom where it closed watertight.

The bed-sediment samples were sieved and the percentage of sediment by weight contained in each size class was recorded for each sample. These data were converted to be expressed as the percentage of sediment in the sample that was finer than each sieve-size class or the cumulative-size distribution of the sample. At each sampling site, a composite cumulativesize distribution was computed as the arithmetic average of the cumulative-size distributions of the samples. The size that corresponded to the midpoint or median size of the composite cumulative-size distribution curve was interpolated for each of the sites. This size is referred to herein as the composite median grain size.

\section{Smith, 1971}

The "bed material was sampled by placing shallow pans in stream-bottom depressions and allowing bed forms to migrate over them. Stream-average samples for each locality [sampling site] were collected by splitting a composite sample of $12-\mathrm{cm}-$ long core specimens gathered at $15-\mathrm{m}$ intervals in two crosschannel traverses" (Smith, 1971). Channel-average median grain sizes were taken directly from table 1 in Smith (1971) for five sampling sites along the Platte River (fig. 2).

\section{Kircher, 1981}

Kircher, 1981 reported cumulative size distributions from bed sediment from 11 sampling sites along the Platte River (fig. 2). "The bed-material samples were obtained using a BMH 60 (Guy and Norman, 1970).....The data listed in table 7 are the weighted mean grain-size distribution of each station, each was determined by giving each sample a weight proportional to the increment of channel it represents."

For some of the sampling sites, the data from table 7 in Kircher (1981) included grain-size distributions for samples collected on multiple days. The arithmetic mean of the percentage finer in each size class for the sampled days was computed, yielding the composite cumulative-size distribution. The composite median grain size was interpolated from the composite cumulative-size distribution.

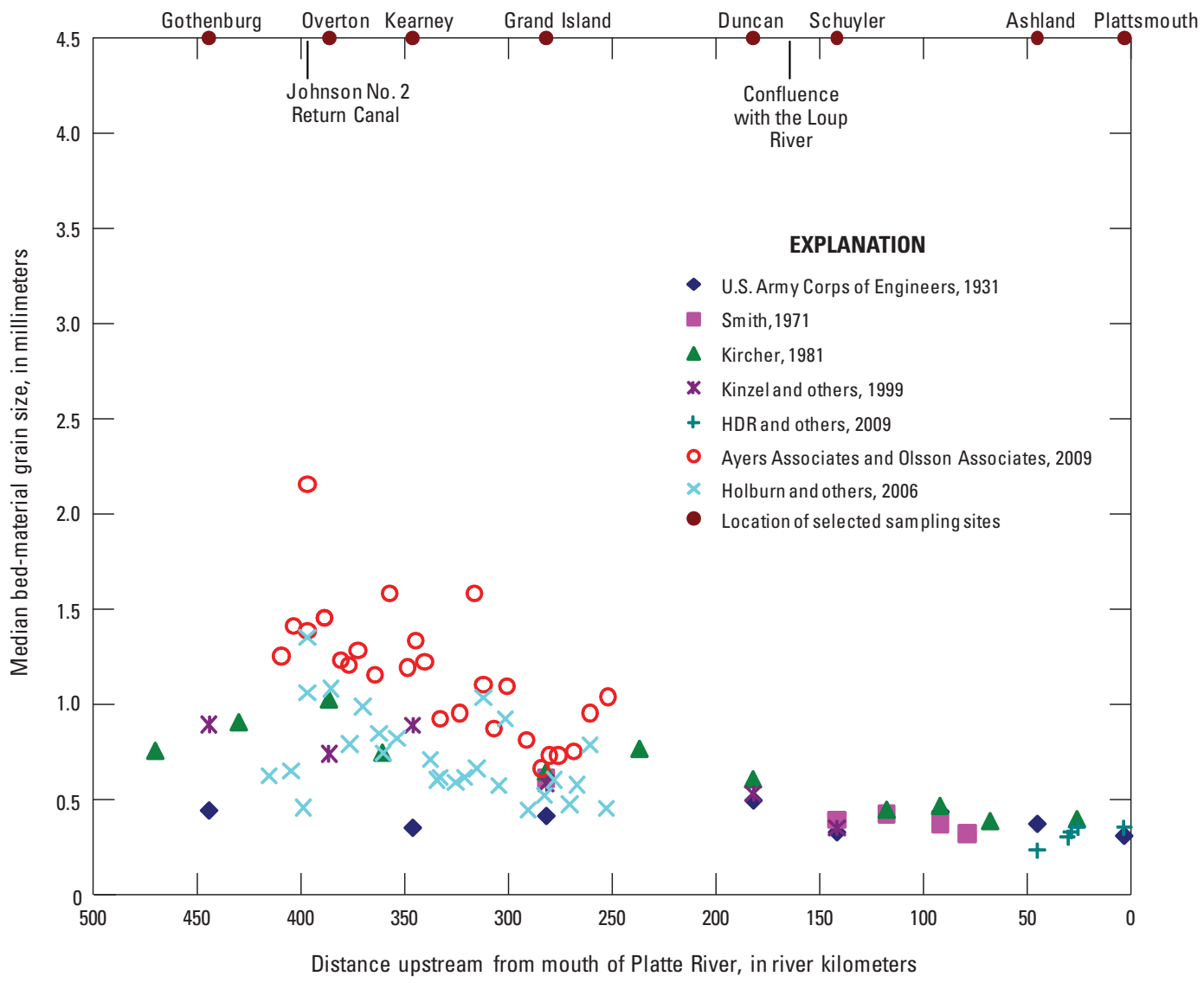

Figure 2. Longitudinal relation of composite median bed-sediment grain size and distance upstream from the mouth of the Platte River. 
A summary of the 1989 bed-sediment sampling effort conducted by the Bureau of Reclamation is included in Holburn and others (2006), and reported, "A hand-held bed material sampler was used where the river channel could be waded. At bridge sites, a standard bed material sampler was lowered. In dry channels, bed-material samples were collected using a shovel."

At each of the 27 sampling sites along the Platte River a composite cumulative-size distribution was computed by averaging the cumulative size distributions of the multiple samples. The composite median grain size was interpolated from the composite cumulative-size distribution computed at each site (fig. 2).

\section{Kinzel and others, 1999}

Kinzel and others (1999) reported a study of six sampling locations along the Platte River (fig. 2), "A BMH-60 bed-material sampler was deployed at each site from a bridge with the aid of a bridgeboard at each site using the methods described by Guy and Norman (1970)."

A composite cumulative-size distribution was determined by averaging the cumulative-size distributions of the samples collected at a site. The composite cumulative-size distribution was used to interpolate a composite median grain size for each site.

\section{HDR and others, 2009}

A habitat-related study reported by HDR and others (2009) focused on the lower Platte River. Sediment samples were collected at five general locations between Ashland and Plattsmouth, Nebr. The sampling sites included the top and upper end of low-level, mid-level, and high sandbars, as well as a few submerged locations adjacent to a bar boundary. Each sample was collected using a standard spade to remove sediment from a single hole to a depth of about 30 centimeters ( 1 foot) (Robert Mussetter, written communication, 2010).

Multiple samples were collected at the five sampling locations. A composite cumulative size distribution was determined by averaging the cumulative-size distributions of the samples collected at a site. The composite cumulative-size distribution was used to interpolate a composite median grain size for each site (fig. 2).

\section{Ayers Associates and Olsson Associates ( 2009}

A second 2009 study reported by Ayers Associates and Olsson Associates (2009) focused on geomorphic characteristics of the middle Platte River. "Bed sediment samples were to be collected using a steel cylinder core sampler. However, because of the coarseness of the material, it became evident that using the steel cylinder core sampler defined in the protocol was both difficult and impractical...Instead, it was determined that a 5-gallon bucket would be more practical for collecting bed material samples and would likely provide the same results. The bucket was pushed 10 to 12 inches deep at an angle into the bed of the channel with the opening facing upstream."

At each of the 26 sites where multiple samples were collected a composite cumulative size distribution was computed by averaging the cumulative size distributions of the samples. The composite median grain size was interpolated from the composite cumulative-size distribution computed at each site (fig. 2).

\section{Comparison of Median Grain Size}

The composite median grain size of the bed sediment at sites from the previous investigators was compiled and is shown in figure 2. The streambed of the Platte River in 1931 was relatively homogeneous throughout the middle and lower Platte River with a composite median grain size ranging from about 0.32 to 0.52 millimeters. Since 1931, the Platte River in the reach from Gothenburg to downstream from Grand Island (river kilometer 444 to approximately 252) has shown greater variability in composite median grain sizes than along the lower Platte River. If the U.S. Army Corps of Engineers' 1931 samples are used as a baseline, the composite median grain size of the bed sediment in the central Platte River has coarsened by less than a factor of about 2 to about 6, with the coarsest composite median grain size measured downstream from Central Public Power and Irrigation District's Johnson No. 2 hydropower return canal outfall by Ayers Associates and Olsson Associates (2009).

The median grain sizes of the individual bed-sediment samples collected in the middle Platte River from Gothenburg to Grand Island for three time periods are shown in figure 3. Although a few coarse (that is median size greater than 1 millimeter) samples were measured in 1931, collectively the median grain sizes of the samples from 1931 are finer than the median grain sizes of the bed-sediment samples from 1998 and 2009.

\section{Discussion}

Standardized bed-sediment samplers, sampling techniques, and data-reduction methods are necessary to have the greatest confidence in detecting spatial and temporal trends in bedsediment size gradations. Whereas the samplers and sampling methods among investigators during the past 78 years along the Platte River were not standardized, it is interesting to note that even with these differences the bed-sediment gradations in the central Platte River have shown a greater degree of variability than those in the lower Platte River. The channels in the central Platte River have undergone dramatic geomorphic transformation in this time period (National Research Council, 2004), and unlike the lower Platte River there are no major tributaries that input sediment. However, water does enter the central Platte through canals. When these canal flows are devoid of sediment, like those from Johnson No. 2 hydropower canal return (figs. 1 and 2), fine material is winnowed from the riverbed, producing a coarser residual bed sediment (Murphy, 2004).

Changes in the size distribution of riverbed sediments are important because the sediment transport capacity is inextricably linked to the sizes on the bed. A coarser riverbed implies that, for the same boundary shear stresses, the post-1931 riverbed in the middle Platte River is less mobile and its morphology less dynamic (Kinzel and others, 1999). Thus, management strategies dependent on the use of streamflow to modify the channel morphology in this reach may need to consider the coarsened bed-sediment sizes available to be mobilized. 


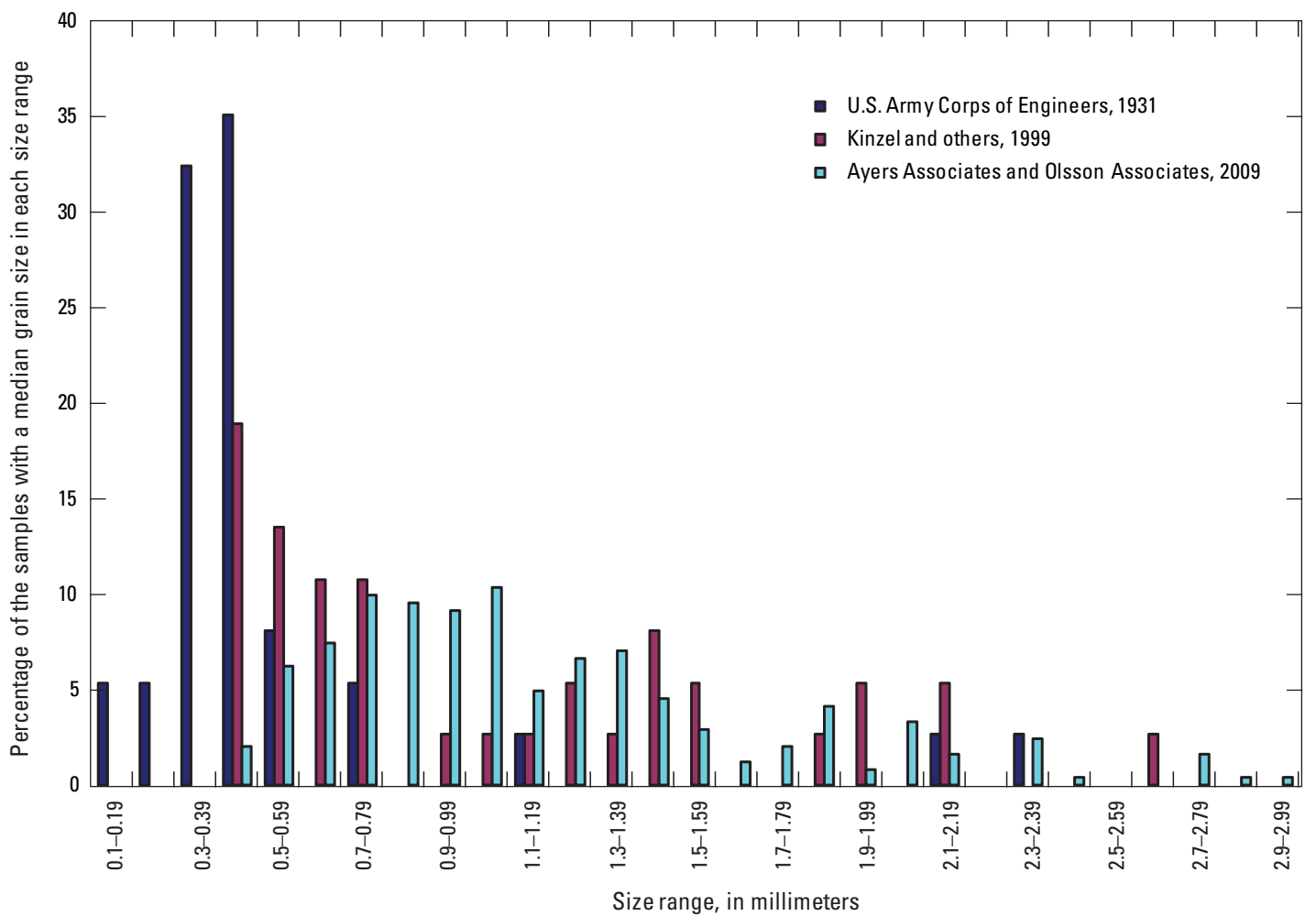

Figure 3. Range and distribution of median grain sizes for bed-sediment samples collected in 1931, 1998, and 2009 along the middle Platte River, Nebraska.

\section{References Cited}

Ayers Associates and Olsson Associates, 2009, Channel geomorphology and in-channel vegetation monitoring of the central Platte River-Year 1 (2009): Fort Collins, Colo., 47 p.

Governance Committee, 2006, Platte River Recovery Implementation Program Cooperative Agreement, 5 p., accessed September 2, 2010, at http://www.platteriverprogram.org/ PubsAndData/ProgramLibrary/PRRIP\%20Program\%20 Cooperative\%20Agreement.pdf

Guy, H.P., and Norman, V.M., 1970, Field methods for measurement of fluvial sediment: U.S. Geological Survey Techniques of Water-Resources Investigations, book 3, chapter C2, 59 p.

HDR, The Flatwater Group, Mussetter Engineering, and Pegg, M., 2009, Lower Platte River Stage Change Study final second progress report-Field work activities: Omaha, Nebr., $62 \mathrm{p}$.

Holburn, E.R., Fotherby, L.M., Randle, T.J., and Carlson, D.A., 2006, Trends of aggradation and degradation along the Central Platte River: 1985 to 2005: Denver, Colo.: U.S. Department of the Interior, Bureau of Reclamation report, 180 p., accessed May 27, 2010 at http://www.usbr.gov/pmts/ sediment/projects/index.html.
Kinzel, P.J., Nelson, J.M., Parker, R.S., Bennett, J.P., and Topping, D.J., 1999, Grain-size evolution of the Platte River, 1931-1998, in Proceedings of the 10th Platte River Basin Ecosystem Symposium, February 23-24, 1999, Kearney, Nebraska, p. 9-14.

Kircher, J.E., 1981, Sediment analysis for selected sites on the South Platte River in Colorado and Nebraska, and the North Platte and Platte Rivers in Nebraska-Suspended sediment, bedload and bed material: U.S. Geological Survey Open-File Report 81-207, 48 p.

Murphy, P.J., 2004, Platte River channel: history and restoration, Bureau of Reclamation: Denver, Colo., 177 p.

National Research Council, 2004, Endangered and threatened species in the Platte River Basin: Washington, D.C., National Academy Press, 299 p.

Smith, N.D., 1971, Transverse bars and braiding in the lower Platte River, Nebraska: Geological Society of America Bulletin, v. 82, p. 3407-3420.

U.S. Army Corps of Engineers, 1931, Silt investigation in the Missouri River basin, mainstem of Missouri River and minor tributaries, appendix XV, supplement V, Sediment characteristics of the Platte River. 